\title{
Antagonistic Activity of Siderophore-Producing Bacteria from Black Rice Rhizosphere against Rice Blast Fungus Pyricularia oryzae
}

\author{
Nabila ${ }^{1}$ and Rina Sri Kasiamdari ${ }^{2 *}$ \\ ${ }^{1}$ Faculty of Biology, Universitas Gadjah Mada. Jl. Teknika Selatan, Sekip Utara Yogyakarta 55281, Indonesia \\ ${ }^{2}$ Plant Systematics Laboratory, Faculty of Biology, Universitas Gadjah Mada. Jl. Teknika Selatan, Sekip Utara, Yogyakarta 55281, Indonesia
}

Received: November 30, 2020 / Revised: January 5, 2021 / Accepted: January 21, 2021

\begin{abstract}
Rice blast caused by Pyricularia oryzae, which is a major threat to food security worldwide, markedly decreases the yield of rice. Some rhizobacteria called 'plant growth-promoting rhizobacteria' inhibit plant pathogens and improve plant growth by secreting iron-chelating siderophores. The decreased availability of iron adversely affects the survival of pathogens, especially fungal pathogens, in the rhizosphere. This study aimed to determine the morphological diversity of siderophore-producing bacteria, analyze the type of siderophores produced by the bacteria, and examine their growth-inhibitory activity against Pyricularia oryzae. The rhizobacteria were isolated from the rhizosphere of Sembada Hitam variety of black rice plants in Pakem, Sleman, Yogyakarta, Indonesia. In total, 12 distinct isolates were screened for the production of siderophores. It was found that 9 out of 12 bacteria produced siderophore and most of them were Gram positive bacteria. The best siderophore-producing isolates with different type of siderophore were used in further studies. The IS3 and IS14 isolates were found to be the best siderophore producer that produced hydroxamate and mixed type of hydroxamate-carboxylate type of siderophore, respectively. In the dual culture assay, IS14 showed a strong antagonistic effect against Pyricularia oryzae by the $81.17 \%$ inhibition.
\end{abstract}

Keywords: Biocontrol, siderophore, rhizobacteria, black rice, Pyricularia oryzae

\section{Introduction}

Rice (Oryza sativa L.) is the most important staple food crops in Indonesia. Among the various types of rice, white rice is the most commonly consumed. However, pigmented rice, especially black rice, has begun to become popular as a functional food because of its health benefits in terms of taste, nutrient, and anthocyanin content [1]. The demand for rice is increasing in line with the increasing population, but unfortunately, rice productivity is often constrained by biotic and abiotic factors. One of the most challenging biotic stresses for

\section{* Corresponding author}

Tel: +62274580839 , Fax: +62274580839

E-mail: rkasiamdari@ugm.ac.id rice production is blast disease. About $12 \%$ of the total paddy fields in Indonesia are attacked by blast disease caused by Pyricularia oryzae. Blast disease causes an enormous reduction in the yield of rice about $30-50 \%$ in Southeast Asia and South America [2].

Blast disease is an important disease in rice, both on dry land and lowland rice [3]. Symptoms of blast disease are characterized by grayish-white rhomboidal spots that develop a brownish margin on the leaves. These pathogens most commonly attack leaves, causing leaf blasts in the vegetative phase, or panicle during the reproductive phase causing neck blasts. The neck blast of a rice panicle is considered to be the most destructive phase of the disease and can occur without severe leaf blasts [4].

Modern agriculture is mostly dependent on the chemi- 
cals in the form of pesticides and fertilizers to maintain agricultural production. However, the use of chemical pesticides and fertilizers has undesirable effects on the environment and can lead to the development of disease resistance [5]. To avoid the negative effects of these chemicals, biocontrol agents could be considered important candidates from a sustainable agriculture point of view. Biocontrol agents are natural enemies that play an important role in controlling the plant disease via predation, parasitism, and pathogenicity or competition. This biological control has specific targets, does not cause phytotoxicity effects, and does not damage the environment [6]. Plant growth-promoting rhizobacteria (PGPR), as biocontrol agents, can act through various mechanisms, for example by producing antagonistic substances or by inducing resistance to pathogens [7].

In this respect, PGPR that produced siderophore has received increasing attention due to their potential as biocontrol agent against harmful phytopathogens and possibility to substitute hazardous pesticides [8]. Siderophores are organic compounds with low molecular weight which functions as an iron chelator. Siderophores are produced by microorganisms to obtain dissolved iron by binding to $\mathrm{Fe}^{3+}$ in the environment and reducing it to $\mathrm{Fe}^{2+}$. This mechanism allows for competition with pathogens for the availability of iron which are essential for their survival. Siderophore-producing bacteria have been reported to improve iron nutrition and slow down the growth of pathogens, especially fungi, by limiting the availability of iron for pathogen [9]. Siderophores have been suggested to be an environmentally friendly alternative to hazardous pesticides [10].

Currently, there is very limited knowledge regarding the diversity of siderophore-producing rhizobacteria from local black rice in Indonesia and its ability to suppress the growth of Pyricularia oryzae, one of the most damaging fungal diseases of rice. The aim of this study were to determine the morphology diversity of siderophore producing bacteria, to analyze the type of siderophore they produced, and to observe their ability to inhibit the growth of Pyricularia oryzae.

\section{Materials and Methods}

\section{Isolation of siderophore producing bacteria}

Rhizosphere soil was collected from local black rice
(Oryza sativa L.) during early vegetative period in Padasan Village, Pakembinangun, Pakem, Sleman, Yogyakarta, Indonesia. The rhizosphere soil samples were randomly collected in triplicates.

For isolation of bacteria, $1 \mathrm{~g}$ of rhizospheric soil sample from each site was serially diluted. The diluted suspension $(0.1 \mathrm{ml})$ from $10^{-4}-10^{-6}$ dilution factor were spread on nutrient agar (NA) medium in triplicates and incubated at $37^{\circ} \mathrm{C}$ for $24 \mathrm{~h}$. The isolated colonies that developed on nutrient agar medium were purified and maintained on NA slants and kept as stock culture at $4{ }^{\circ} \mathrm{C}$.

Bacterial isolates were screened for siderophoreproducing ability by universal chrome azurol sulfonate (CAS) assay. The CAS reagent was prepared according to Schwyn and Neilands [11]. Before starting the experiment, all glassware was rinsed with $3 \mathrm{~mol} / \mathrm{l}$ hydrochloric acid $(\mathrm{HCl})$ to remove iron and subsequently washed in deionized water [12]. Briefly, $60.5 \mathrm{mg}$ chrome azurol S


$10 \mathrm{ml} 1 \mathrm{mM}$ ferric chloride $\left(\mathrm{FeCl}_{3} \cdot 6 \mathrm{H}_{2} \mathrm{O}\right)$ solution that prepared in $10 \mathrm{mM} \mathrm{HCl}$. The hexadecyltrimethylammo-


slowly added to CAS and ferric chloride mixture. The mixture was then autoclaved. CAS agar plates were prepared by mixing $100 \mathrm{ml}$ CAS reagent in $900 \mathrm{ml}$ sterilized LB agar medium with pH 6.8 [13]. A loopful of each bacterial isolates were spot inoculated on CAS agar plates and incubated at $30^{\circ} \mathrm{C}$ for $48 \mathrm{~h}$. The formation of orange zone around the bacterial colonies was observed [14].

\section{Qualitative assay}

Determination of siderophore production (qualitative and quantitative) was carried out by CAS assay. Selected bacterial cultures were grown in LB broth medium at $30^{\circ} \mathrm{C}$ for $24 \mathrm{~h}$ on rotary shaker $(200 \mathrm{rpm})$. The bacterial suspension containing $1 \times 10^{8}$ cells ml $^{-1}$ was centrifuged at $10.000 \mathrm{rpm}$ for $15 \mathrm{~min}$. Five wells were made in each CAS agar plate and filled with $60 \mu \mathrm{l}$ supernatant [15]. The plates were then incubated at room temperature for 7 days and measurements of the diameter of orange halo were taken at the end of incubation period [16].

\section{Quantitative assay}

The bacterial cultures grown in LB broth medium con- 
taining $1 \times 10^{8}$ cells ml ${ }^{-1}$ was centrifuged at $10.000 \mathrm{rpm}$ for $15 \mathrm{~min}$. A $0.5 \mathrm{ml}$ supernatant of each bacterial cultures was mixed with $0.5 \mathrm{ml}$ CAS reagent and incubated in room temperature for $20 \mathrm{~min}$. The optical density was taken at $630 \mathrm{~nm}$ using spectrophotometer (Thermo Scientific). Percent siderophore unit (psu) was calculated according to the following formula [17]:

$$
[(\mathrm{Ar}-\mathrm{As}) / \mathrm{Ar}] \times 100
$$

where $\mathrm{Ar}$ and As are the absorbance of reference solution (mixture of CAS reagent and un-inoculated broth) and absorbance of sample (mixture of CAS reagent and supernatant of sample), respectively.

\section{Detection of the type of siderophore}

For the detection of the type of siderophore, Fissglucose minimal media was used as an iron-restricted media [18]. Each bacterial cultures was grown in Fissglucose minimal media at $30^{\circ} \mathrm{C}$ for $24 \mathrm{~h}$. Afterwards, it was centrifuged at $10,000 \mathrm{rpm}$ for $15 \mathrm{~min}$ to obtain culture supernatant.

Detection of hydroxamate type of siderophore was done by Tetrazolium assay. To $1 \mathrm{ml}$ of the culture supernatant, 1-2 drops of $2 \mathrm{~N} \mathrm{NaOH}$ and a pinch of tetrazolium salt were added. The appearance of a deep red colour instantly, indicated hydroxamate siderophores.

For detection of catecholate siderophore, Arnow's assay was used. This test was performed by adding $1 \mathrm{ml} 0.5 \mathrm{M}$ $\mathrm{HCl}$ and $1 \mathrm{ml}$ Nitrite-Molybdate reagent to $1 \mathrm{ml}$ culture supernatant. Catechol gives a yellow color when reacted with nitrous acid. Afterwards, $1 \mathrm{ml} 1 \mathrm{M} \mathrm{NaOH}$ was added and allowed to incubate for $5 \mathrm{~min}$ for the reaction to occur completely. The formation of intense orange-red indicated the presence of catechol compound [19]. Absorbance was measured at $495 \mathrm{~nm}$ [20].

Carboxylate type of siderophore was determined by Spectrophotometric assay, following the methodology of Shenker et al. [21]. To $1 \mathrm{ml}$ of culture supernatant, $1 \mathrm{ml}$ of $250 \mu \mathrm{M} \mathrm{CuSO}_{4}$ and $2 \mathrm{ml}$ of acetate buffer ( $\left.\mathrm{pH} 4\right)$ were added. Peak of absorption of siderophores were monitored in the wavelength range of 190-280 $\mathrm{nm}$ [22].

\section{Isolation of fungal pathogen}

Infected rice samples were collected from rice fields in Godean, Sleman, Yogyakarta, Indonesia. The isolation of Pyricularia oryzae was carried out as described by
Wicaksono et al. [23] with some modifications. Infected panicle were cut crosswise to $7 \mathrm{~cm}$ in size and incubated on wet wipes in a closed petri dish. Incubation was carried out at room temperature for 2 days in a light condition. Conidia arising from the surface of the plant tissue were then observed with a stereomicroscope. Furthermore, the oatmeal agar (OMA) medium in a petri dish was sliced $2 \times 2 \mathrm{~cm}$ in size and placed on a sterile glass slide. The glass slides and OMA media were placed on a wet wipes in a closed petri dish. Conidia were taken with a sterile sewing needle and then transferred to the surface of the OMA media. After 7-10 days, the conidia were observed to confirm the morphological characteristics of Pyricularia oryzae. Then it was transfered to potato dextrose agar (PDA) media and stored at $4{ }^{\circ} \mathrm{C}$ for further tests.

\section{Molecular identification of fungal pathogen}

Molecular identification of fungal pathogen was carried out from the culture of fungal mycelium (ISPOG). Genomic DNA was extracted using Zymo QuickDNA Fungal/Bacterial Miniprep Kit (D6005). Amplification of ITS region was using MyTaq HS RedMix (Bioline 25048). Primer ITS1 - 5'TCCGTAGGTGAACCTGCGG3' and ITS4 - 5'TCCTCCGCTTATTGATATGC3' were used in this experiment [24]. PCR reactions were performed

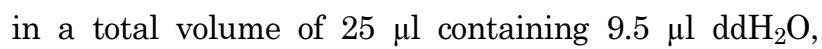
$12.5 \mu \mathrm{l}$ MyTaq Red Mix [2x], $1 \mu \mathrm{l} 10 \mu \mathrm{M}$ ITS1 and ITS4 primer, and $1 \mu \mathrm{l}$ DNA template. The PCR program begins with an initial denaturation at $95^{\circ} \mathrm{C}$ for $3 \mathrm{~min}$. The amplification process is 35 cycles consist of denaturation at $94^{\circ} \mathrm{C}$ for $30 \mathrm{sec}$, annealing at $54^{\circ} \mathrm{C}$ for $30 \mathrm{sec}$, extension at $72^{\circ} \mathrm{C}$ for $1 \mathrm{~min}$ and last cycle was hold at $4^{\circ} \mathrm{C}$. The PCR product was then purified and sequenced using bidirectional sequencing method. The sequences was edited by using BioEdit Sequence Alignment Editor. Sequence data was aligned with publicly available sequences through the BLAST program (BLASTn) at the National Biotechnology Information Center (NCBI). Phylogenetic tree analysis was done using Molecular Evolutionary Genetics Analysis X (MEGA version X) software.

\section{Antagonism in vitro}

The two most productive isolates which exhibited differences in siderophore functional groups (IS3 and IS14) 
were selected to be tested against rice blast pathogen Pyricularia oryzae using dual culture technique. Seven days old mycelia disc (5 $\mathrm{mm}$ diameter) was placed in the center of each plate. Each bacterial isolates were streaked $3 \mathrm{~cm}$ away from the fungal disc. The plates were incubated at $30^{\circ} \mathrm{C}$ for 10 days. Distance of inhibition between the edge of bacterial and fungal colonies was measured and calculated using the formula

$$
\% \mathrm{I}=(\mathrm{C}-\mathrm{T}) /(\mathrm{C}) \times 100
$$

where $\mathrm{I}=$ inhibition of mycelial growth, $\mathrm{C}=$ growth of fungal colonies in the control plate, and $\mathrm{T}=$ growth of fungal colonies in dual cultures [25].

\section{Statistical analysis}

Statistical analysis was carried out on quantitative assay of siderophore production and antagonism assay. The data were statistically analyzed by one-way ANOVA followed by Duncan's multiple range test $(p<0.05)$ using IBM SPSS Statistics 23.0 software.

\section{Results and Discussion}

\section{Isolation of siderophore producing bacteria}

A total of 12 bacterial isolates were isolated from rhizosphere of local black rice based on colony morphology.
All isolates were screened for siderophore production by inoculating a loopful of culture isolates on CAS medium. Of these, 9 isolates were siderophore positive as indicated by the formation of orange zones on CAS medium. The 9 bacterial isolates were further characterized based on morphological properties (Table 1).

In this study, six selected bacteria are Gram-postive and the rest are Gram-negative. Among all the bacterial tested, some aerobic bacteria produced the fastest color change reaction on CAS medium. It was reported that most aerobic and facultative anaerobic microorganisms are produced siderophores to combat low iron stress [26].

\section{Qualitative and quantitative assay}

The capacity of selected bacteria to produce siderophore was observed qualitatively and quantitatively by performing CAS assay. For both assay, each bacterial suspensions containing $1 \times 10^{8}$ cells ml ${ }^{-1}$ were used. The positive reaction of qualitative assay results in color change of CAS-agar medium from blue to orange. Out of nine cultures, only four bacterial isolates grown on CASagar medium and exhibits orange zone. The diameters (cm) of orange zone produced by these isolates from the highest to the lowest are 2.79 (IS3), 2.05 (IS14), 1.85 (IS1), and 1.24 (IS4). The other five isolates did not grow on CAS-agar medium. Other reports by Chaiharn et al.

Table 1. Characterization of siderophore producing bacteria.

\begin{tabular}{|c|c|c|c|c|c|c|c|c|c|}
\hline \multirow{2}{*}{ Characters } & \multicolumn{9}{|c|}{ Isolates name } \\
\hline & IS1 & IS3 & IS4 & IS5 & IS6 & IS10 & IS11 & IS13 & IS14 \\
\hline Form & Irregular & Irregular & Circular & Rhizoid & Circular & Circular & Punctiform & Circular & Filamentous \\
\hline Elevation & Convex & Convex & Flat & Flat & Convex & Convex & Convex & Convex & Flat \\
\hline Margin & Undulate & Lobate & Entire & Filamentous & Entire & Entire & Entire & Entire & Filamentous \\
\hline Texture & Smooth & Smooth & Smooth & Contoured & Concentric & Contoured & Smooth & Smooth & Smooth \\
\hline Colour & Opaque & White & Yellow & White & Cream & Cream & Opaque & Orange & White \\
\hline Slant & Filiform & Echinulate & Beaded & Rhizoid & Filiform & Filiform & Filiform & Beaded & Echinulate \\
\hline Stab & Filiform & Filiform & Filiform & Arborescent & Filiform & Filiform & Filiform & Filiform & Filiform \\
\hline Motility & - & - & - & + & - & - & - & - & - \\
\hline $\begin{array}{l}\text { Oxygen } \\
\text { requirement }\end{array}$ & Anaerobic & Aerobic & Anaerobic & Anaerobic & Anaerobic & Anaerobic & $\begin{array}{l}\text { Facultative } \\
\text { anaerobic }\end{array}$ & $\begin{array}{l}\text { Facultative } \\
\text { anaerobic }\end{array}$ & Aerobic \\
\hline Shape & Rods & Rods & $\begin{array}{c}\text { Cocci in } \\
\text { grapes like } \\
\text { bunches }\end{array}$ & Rods & $\begin{array}{l}\text { Rods in } \\
\text { chains }\end{array}$ & $\begin{array}{l}\text { Rods in } \\
\text { chains }\end{array}$ & Rods & Short rods & Rods \\
\hline Gram reaction & - & + & - & + & + & + & + & + & - \\
\hline $\begin{array}{l}\text { Endospre } \\
\text { staining }\end{array}$ & - & + & - & + & - & - & - & - & - \\
\hline
\end{tabular}




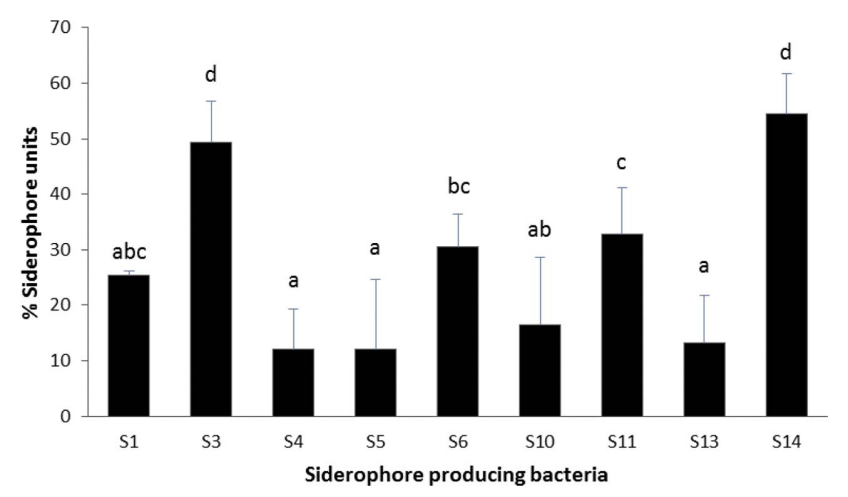

Fig. 1. Quantification of siderophore produced by rhizobacterial isolates. Values followed by different alphabets indicate statistically significant difference between treatment (DMRT test; $p \leq 0.05)$.

(2009) have also found that some isolates did not grow on CAS agar. It is suggested that this was caused by the interference of detergent hexadecyltrimethyl-ammonium bromide (HDTMA) contained in the CAS medium which is toxic mainly to fungi and Gram-positive bacteria [27].

For quantitative assay, all 9 isolates were able to produce siderophore based on measurements of OD at $630 \mathrm{~nm}$. The percentage of siderophore units varied from $12.17 \%$ (IS4 and IS5) to $54.55 \%$ (IS14) (Fig. 1). The formation of orange zone on CAS-agar medium occurs because iron is removed from $\mathrm{CAS}-\mathrm{Fe}^{3+}$ complex during siderophore production. The CAS and $\mathrm{Fe}^{3+}$ forms a tight complex to create the blue color in the medium. The presence of siderophore in the medium causes it to bind to $\mathrm{Fe}^{3+}$ and turned the color from blue to orange [28].

Table 2. Chemical nature of siderophores produced by nine rhizobacterial isolates.

\begin{tabular}{ccccc}
\hline Isolates & $\begin{array}{c}\text { Tetrazolium } \\
\text { assay } \\
\text { (hydroxamate) }\end{array}$ & $\begin{array}{c}\text { Arnow } \\
\text { (catecholate) }\end{array}$ & $\begin{array}{c}\text { Peak at } \\
495 \mathrm{~nm}\end{array}$ & $\begin{array}{c}\text { Peak at } \\
\text { (catecholate) }\end{array}$ \\
$\begin{array}{c}\text { (carboxylate) } \\
\text { (carbo nm }\end{array}$ \\
\hline IS1 & + & - & - & - \\
IS3 & + & - & - & - \\
IS4 & + & - & - & - \\
IS5 & + & - & - & - \\
IS6 & + & - & - & - \\
IS10 & + & - & - & - \\
IS11 & + & - & - & - \\
IS13 & + & - & - & - \\
IS14 & + & - & - & + \\
\hline
\end{tabular}

\section{Detection of the type of siderophore}

The type of siderophore produced by bacteria could be categorized as hydroxamate, catecholate and carboxylate compounds by performing specific chemical tests. All bacterial isolates were grown under iron-limiting conditions in Fiss-glucose minimal medium to induce siderophore productions. All of our isolates were positive for hydroxamate type of siderophore and none of the isolates produced catecholate siderophore. The carboxylate type of siderophores was detected in one isolate namely IS14 (Table 2). It was reported that several soil bacteria could produce more than one type of siderophore. Hydroxamate and catecholate are the most common type [29]. In this study, one of our isolates produced hydroxamate and carboxylate type of siderophore. This result is similar with the previous study which some isolates produced both hydroxamate and catecholate type of siderophore [30].

Siderophore is a powerful ferric iron-chelating molecules that produced by microorganisms to acquire the iron essential for growth. Siderophores are known to differ from one another in their chemical structure and properties. Hydroxamate siderophores are produced by bacteria and fungi, while catecholate only produced by bacteria. Carboxylates siderophores are produced by a few bacteria and exclusively by the fungi of the order Mucorales [31]. The most commonly found siderophores are hydroxamate siderophores [32].

\section{Isolation of fungal pathogen}

Pyricularia oryzae infects the rice plants by penetrating directly through the plasma membrane using strong biological turgor pressure. This fungal pathogen most commonly attacks leaves or panicles of the rice plant [33]. In this study, the blast pathogen was isolated from infected panicles. The infected panicles were cut crosswise to $7 \mathrm{~cm}$ in size and incubated on wet wipes in a closed petri dish. After two days, the panicles was placed under a stereomicroscope to check for sporulation (Fig. 2A). A few conidia was picked with sterile needle and placed on sliced OMA medium inside a moist petri dish (Fig. 2B). The conidia was first detected at the day-8 after inoculated on OMA medium (Fig. 2C). Kulmitra et al. [34] reported that among different media used, OMA medium is the most appropriate for cultural study of rice blast fungus $P$. oryzae. 

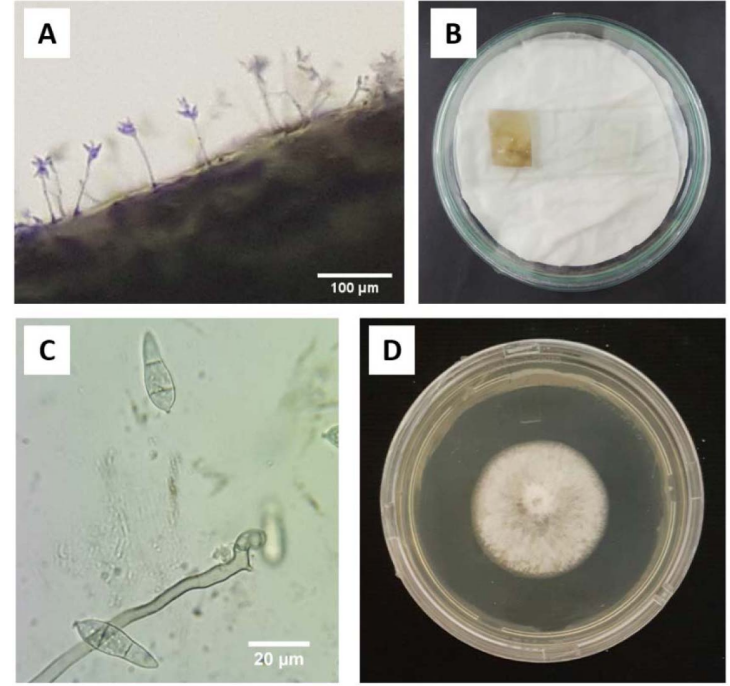

Fig. 2. Isolation of fungal pathogen. (A) Conidiophore sporulating on rice panicle, (B) Oatmeal agar (OMA) medium inside a moist petri dish, (C) Conidia of Pyricularia oryzae observed under the light microscope, (D) Seven days old fungal mycelia on PDA medium.

Fungal isolate obtained in this study was named as ISPO-G. The shape of conidia observed under the light microscope were pyriform with a rounded base and narrowed apex. The color is gray, two septate and three cells with approximate length and width of $26.95 \pm 0.268 \mu \mathrm{m}$ and $7.98 \pm 0.236 \mu \mathrm{m}$, respectively (Fig. 2C). These results are consistent with earlier studies which showed that the length of conidia ranged from $22.76-28.56 \mu \mathrm{m}$ and width 7.85-9.21 $\mu \mathrm{m}$ [35]. The isolate was then subcultured to PDA medium and incubated for 7 days to undergone molecular identification (Fig. 2D).

\section{Molecular identification of fungal pathogen}

Molecular identification of fungal pathogen was conducted to confirm the identity of obtained isolate. The molecular analysis was done by DNA extraction, PCR amplification using ITS primers followed by bidirectional sequencing. The sequence was compared with related DNA sequence databases GenBank through the BLASTn program in NCBI. BLAST analysis showed that isolate ISPO-G was closely related to Pyricularia oryzae strain Pos-1 with $99.40 \%$ similarity. The phylogenetic tree analysis were further analysed with MEGA X. Reconstruction of the phylogenetic tree was based on the Neighbor-joining (NJ) method with Jukes-Cantor model (Fig. 3).

\section{Antagonism in vitro}

The two isolates that produced most siderophores from quantitative assay were tested against Pyricularia oryzae by dual culture method. This method has been widely used for screening of biocontrol agents including fungi and bacteria. By this method, the biocontrol agent and pathogen would interact on a solid medium. The percent of inhibition was recorded by observing the inhibition zone or overgrowth of the pathogen by biocontrol agent [36]. This assay was conducted to select poten-



0.010

Fig. 3. Phylogenetic tree showing the position of an isolate ISPO-G compared to its related Pyricularia oryzae species. Numbers at the nodes indicate the percentage of bootstrap values based on 1000 replicates. 


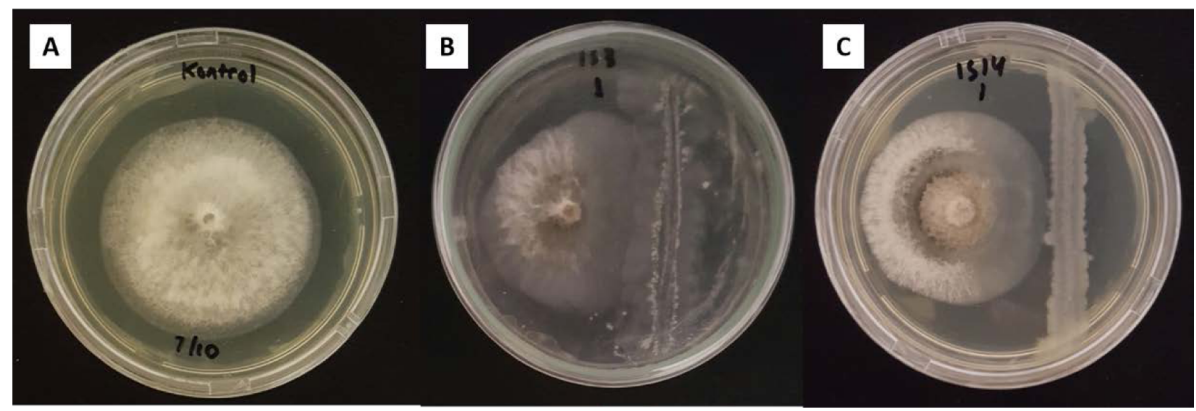

Fig. 4. In vitro antagonism assay. (A) Control, (B) IS3 isolate, (C) IS14 isolate.

tially effective biocontrol agents capable of inhibiting the growth of fungal pathogens.

The in vitro assay showed that both IS3 and IS14 isolates effective to suppress the growth of $P$. oryzae (Fig. 4). The IS3 and IS14 isolates showed inhibition percentage of $70.8 \%$ and $81.17 \%$, respectively. The previous assay conducted by Chaiharn et al. [27] showed that the inhibition percentage of siderophore-producing bacteria isolated from white rice rizosphere against $P$. oryzae varied between $19 \%$ and $84.5 \%$.

In soil, siderophores act as a virulence factor in many pathogenic microorganisms. When the siderophores are produced by microorganisms under low-iron conditions, the other organisms cannot utilize the resulting ferricsiderophore complex. The producing strain can utilize this complex via a very specific receptor in its outer cell membrane, so that the growth of pathogens may be restricted [37]. The previous studies reported that microorganisms which are able to produce siderophores show competitive advantages as compared to those that do not produce them [38]. In conclusion, IS14 isolate of siderophore-producing bacteria appears to be the most potential agents for the inhibition of P.oryzae with antagonistic activity by $81.17 \%$.

\section{Acknowledgments}

This research was financially supported by 'Rekognisi Tugas Akhir (RTA) 2020' Grant from Universitas Gadjah Mada (UGM), Indonesia (No. 2488/UN1.P.II/DIT-LIT/PT/2020).

\section{Conflict of Interest}

The authors have no financial conflicts of interest to declare.

\section{References}

1. Ryu SN, Park SZ, Ho CT. 1998. High performance liquid chromatographic determination of anthocyanin pigments in some varieties of black rice. J. Food Drug Anal. 6: 729-736.

2. Shimamoto K, Takahashi A, Kawasaki T. 2001. Molecular signaling in disease resistance of rice. Rice Gen. 4: 323-333.

3. Shahriar SA, Imtiaz AA, Hossain MB, Husna A, Eaty MNK. 2020. Review: Rice blast disease. Annu. Res. Rev. Biol. 35: 50-64.

4. Zhu YY, Fang H, Wang YY, Fan JX, Yang SS, Mew TW, et al. 2005. Panicle blast and canopy moisture in rice cultivar mixtures. Phytopathology 95: 433-438.

5. Prashar P, Shah S. 2016. Impact of Fertilizers and Pesticides on Soil Microflora in Agriculture. Springer International Publishing, Switzerland.

6. Sigee DC. 1993. Bacterial Plant Pathology: Cell and Molecular Aspects. Cambridge University Press, Cambridge, UK.

7. Glick BR. 1995. The enhancement of plant growth by free-living bacteria. Can. J. Microbiol. 41: 109-117.

8. Saha M, Sarkar S, Sarkar B, Sharma BP, Bhattacharjee S, Tribedi P. 2016. Microbial siderophores and their potential applications: a review. Environ. Sci. Pollut. Res. Int. 23: 3984-3999.

9. Bano A, llyas N. 2012. Potential use of soil microbial community in agriculture. In D. K. Maheshwari (ed.), Bacteria in Agrobiology: Plant Probiotics, pp. 45-64. Springer, Berlin/Heidelberg, Germany.

10. Schenk PM, Carvalhais LC, Kazan K. 2012. Unraveling plantmicrobe interactions: can multi-species transcriptomics help? Trends Biotechnol. 30: 177-184.

11. Schwyn B, Neilands JB. 1987. Universal chemical assay for the detection and determination of siderophores. Anal. Biochem. 160: 47-56.

12. Cabaj A, Kosakowska A. 2009. Iron-dependent growth of and siderophore production by two heterotrophic bacteria isolated from brackish water of the southern Baltic Sea. Microbiol. Res. 164: 570-577.

13. Lakshmanan V, Shantharaj D, Li G, Seyfferth AL, Sherrier DJ, Bais HP. 2015. A natural rice rhizospheric bacterium abates arsenic accumulation in rice (Oryza sativa L.). Planta 242: 1037-1050.

14. Ariole CN, Onuorah AA, Stanley HO. 2019. Diversity and antibacterial potential of siderophore producing bacteria isolated from 
marine fish species. J. Appl. Sci. 19: 343-348.

15. Storey EP. 2005. Isolation, purification, and chemical characterization of the dihydroxamate-type siderophore, "Schizokinen," produced by Rhizobium leguminosarum IARI 917. [Dissertation]. East Tennessee State University, Johnson City, USA.

16. Arora NK, Verma M. 2017. Modified microplate method for rapid and efficient estimation of siderophore produced by bacteria. 3 Biotech 7: 381.

17. Payne SM. 1994. Detection, isolation and characterization of siderophores. Methods Enzymol. 235: 329-344.

18. Vellore JM. 2001. Iron acquisition in Rhodococcus erythrolpolis: the isolation of mutant(s) that do not produce a siderophore. [Dissertation]. East Tennessee State University, Johnson City, USA.

19. Ferreira CMH, Vilas-Boas A, Sousa CA, Soares HMVM, Soares EV. 2019. Comparison of five bacterial strains producing siderophores with ability to chelate iron under alkaline conditions. $A M B$ Express 9: 78.

20. Neilands JB. 1981. Iron absorption and transport in microorganisms. Ann. Rev. Nutr. 1: 27-46.

21. Shenker M, Ghirlando R, Oliver I, Helmann M, Hadar Y, Chen Y. 1995. Chemical structure and biological activity of a siderophore produced by Rhizopus arrhizus. Soil Sci. Soc. Am. J. 59: 837-843.

22. Dave BP, Anshuman K, Hajela P. 2006. Siderophores of halophilic archaea and their chemical characterization. Indian J. Exp. Biol. 44: 340-344.

23. Wicaksono D, Wibowo A, Widiastuti A. 2017. Isolation method of Pyricularia oryzae the causal agent of rice blast disease. J. HPT Tropika. 17: 62-69.

24. Singha IM, Yelena K, Unni BG, Das J, Kalita MC. 2016. Identification and characterization of Fusarium sp. using ITS and RAPD causing fusarium wilt of tomato isolated from Assam, North East India. J. Genet. Eng. Biotechnol. 14: 99-105.

25. Reddy P, Rani J, Reddy MS, Kumar K. VK. 2019. Siderophore isolation and its biocontrol action against rice fungal pathogens. Arch. Biochem. Mol. Biol. 1: 01-06.

26. Khan A, Singh P, Srivastava A. 2018. Synthesis, nature and utility of universal iron chelator-Siderophore: A review. Microbiol. Res. 212-213: 103-111.

27. Chaiharn M, Chunhaleuchanon S, Lumyong S. 2009. Screening siderophore producing bacteria as potential biological control agent for fungal rice pathogens in Thailand. World J. Microbiol. Biotechnol. 25: 1919-1928.

28. Kumar V, Menon S, Agarwal H, Gopalakrishnan D. 2017. Characterization and optimization of bacterium isolated from soil samples for the production of siderophores. Resource-Efficient Technol. 3: 434-439.

29. Kumar P, Thakur S, Dhingra GK, Singh A, Pal MK, Harshvardhan $\mathrm{K}$, et al. 2018. Inoculation of siderophore producing rhizobacteria and their consortium for growth enhancement of wheat plant. Biocatal. Agric. Biotechnol. 15: 264-269.

30. Maheshwari R, Bhutani N, Suneja P. 2019. Screening and characterization of siderophore producing endophytic bacteria from Cicer arietinum and Pisum sativum plants. J. Appl. Biol. Biotechnol. 7: 7-14.

31. Ghavami N, Alikhani HA, Pourbabaei AA, Besharati H. 2017. Effects of two new siderophore-producing rhizobacteria on growth and iron content of maize and canola plants. J. Plant Nutr. 40: 736-746.

32. Saha M, Sarkar S, Sarkar B, Sharma BP, Bhattacharjee S, Tribedi P. 2016. Microbial siderophores and their potential applications: a review. Environ Sci. Pollut. Res. 23: 3984-3999.

33. Yulianto. 2017. Integrated disease control of rice blast. Iptek Tanaman Pangan. 12: 25-34.

34. Kulmitra AK, Sahu N, Sahu DK, Kumar VBS. 2017. In vitro evaluation of animal products against Pyricularia oryzae (Cav.) causing rice blast disease. J. Entomol. Zool. Stud. 5: 98-101.

35. Gupta DR, Surovy MZ, Mahmud NU, Chakraborty M, Paul SK, Hossain MS, et al. 2020. Suitable methods for isolation, culture, storage and identification of wheat blast fungus Magnaporthe oryzae Triticum pathotype. Phytopathol. Res. 2: 30.

36. Law JWF, Ser HL, Khan TM, Chuah LH, Pusparajah P, Chan KG, et al. 2017. The potential of Streptomyces as biocontrol agents against the rice blast fungus Magnaporthe oryzae (Pyricularia oryzae). Front. Microbiol. 8: 3.

37. Shanmugaiah V, Nithya K, Harikrishnan H, Jayaprakashvel M, Balasubramanian N. 2015. Sustainable Approaches to Controlling Plant Pathogenic Bacteria. Taylor \& Francis Group, Boca Raton.

38. Montealgre JR, Rayes R, Perez LM, Herrera R, Silva $P$, Besoain $X$. 2003. Selection of bioantagonistic bacteria to be used in biological control of Rhizoctonia solani in tomato. Electron. J. Biotechnol. 6: 115-127. 